\title{
PERBANDINGAN METODE ARIMA (BOX JENKINS) DAN ARFIMA DALAM PERAMALAN JUMLAH KASUS DEMAM BERDARAH DENGUE DI RUMAH SAKIT HASAN SADIKIN BANDUNG
}

\author{
PARIDI \\ Universitas Gunung Rinjani \\ Email. paridi.faza@gmail.com
}

\begin{abstract}
Abstrak. Peramalan adalah suatu proses yang bertujuan menduga suatu kejadian yang akan datang dan merupakan alat bantu yang penting dalam perencanaan yang efektif dan efisien. Metode peramalan merupakan metode yang berfungsi untuk memprediksi data runtun waktu beberapa periode yang akan datang berdasarkan data di masa lalu, yang dinyatakan dalam bentuk persamaan matematis. Beberapa metode pemodelan time series telah dikembangkan yaitu metode ARIMA(Autoregressive Integrated Moving Average) atau juga dikenal dengan metode Box-Jenkins dan metode ARFIMA (Autoregressive Fractionally Integreted Moving Average).
\end{abstract}

\section{Kata Kunci: Metode Irama, Afrima, Demam Berdarah, Rumah Sakir Hasan Sadikin}

\section{PENDAHULUAN}

Metode peramalan melalui analisis suatu variabel yang akan diperkirakan dengan variabel atau fungsi waktu, dikenal sebagai metode hubungan time series. Time series merupakan serangkaian data pengamatan yang terjadinya berdasarkan urutan waktu (Box, Jenkins dan Reinsel, 1994). Analisis data time series dapat digunakan untuk mengetahui perkembangan satu atau beberapa kejadian dan hubungan atau pengaruhnya pada kejadian lainnya, sekaligus menghitung secara kuantitatif besarnya pengaruh suatu kejadian dengan kejadian lainnya apabila berhubungan. Data time series juga dapat digunakan untuk membuat ramalan berdasarkan garis regresi atau trend.

Beberapa metode pemodelan time series telah dikembangkan. Metode yang paling umum digunakan adalah ARIMA (Autoregressive Integrated Moving Average). Menurut Box dan Jenkins (1976), metode ARIMA atau juga dikenal dengan metode Box-Jenkins merupakan salah satu bentuk analisis deret waktu (time series analysis). Model ARIMA dapat menganalisis data secara univariat yang mengandung pola musiman maupun trend. Metode ini hanya menganalisis data yang stasioner, sehingga data yang tidak stasioner harus distasionerkan terlebih dahulu dengan transformasi atau pembedaan. Model ARIMA juga bisa digunakan untuk mengatasi masalah sifat keacakan, trend, musiman bahkan sifat siklis data time series yang dianalisis. ARIMA sangat efektif digunakan untuk memodelkan data yang tidak stasioner, yang ditunjukkan oleh plot ACF yang turun secara eksponensial atau membentuk gelombang sinus. Ada beberapa data yang tidak stasioner dan plot ACF-nya tidak turun secara eksponensial melainkan secara lambat atau hiperbolik. Data seperti inilah yang dikategorikan sebagai time series memori jangka panjang (long memory). Untuk memodelkan time series jangka panjang, Hosking (1981) telah memperkenalkan model ARFIMA (Autoregressive Fractionally Integreted Moving Average). ARFIMA dapat mengatasi kelemahan model ARIMA, dimana ARIMA hanya dapat menjelaskan time series jangka pendek (short memory), sedangkan ARFIMA dapat menjelaskan baik jangka pendek maupun jangka panjang.(Sowell, 1992).

TINJAUAN PUSTAKA

\section{Model ARIMA (Autoregressive Integrated} Moving Average)

Model ARIMA diaplikasikan untuk deret waktu yang mempunyai mean atau varians yang tidak konstan, atau mempunyai kedua sifat tersebut. Sifat ini disebut sebagai proses yang tidak stasioner. Jika data yang digunakan mengandung pola musiman, maka model yang digunakan adalah SARIMA $(p, d, q)(P, D, Q)^{s}$. Sedangkan apabila model ARIMA memiliki pola musiman ganda, maka model yang digunakan adalah DSARIMA 


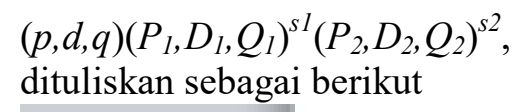

dapat

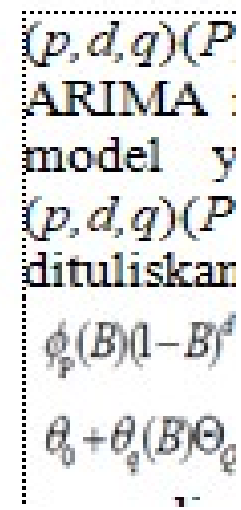

Tahapan analisis data metode ARIMA meliputi: Eksplorasi data, Tahapan Metode ARIMA, dan menghitung MAPE, MAD dan $M S D$. Tahapan Metode ARIMA sendiri terdiri dari beberapa tahap yaitu: (a) Tahap identifikasi dengan pengidentifi kasian model yang dianggap paling sesuai dengan melihat plot ACF dan PACF dari correlogram; (b) Tahap estimasi parameter dengan penaksiran terhadap parameter dalam model tersebut; (c) Tahap uji diagnostik: untuk menguji kesesuaian dari parameter yang didapat pada tahap sebelumnya; (d) Tahap peramalan/penerapan: dilakukan setelah model yang sesuai teridentifikasi.

\section{Autoregressive Fractionally Integrated} Moving Average (ARFIMA)

Suatu proses dikatakan mengikuti model Autoregressive Fractionally Integrated Moving Average jika operator pembedaan dalam model adalah real. ARFIMA disebut juga ARIMA yang nilai operator pembedaan $d$ tidak hanya berupa nilai integer, melainkan termasuk juga nilai-nilai real yang disebabkan oleh adanya memori jangka panjang. Model ARFIMA $(p, d, q)$ dapat ditulis (Ooms \& Doornik, 1999)

\section{$\square \square B \square \square^{d} \square y_{t} \square \square_{t} \square \square \square \square \square \square B \square \square_{t}$,} $t \square 1,2, \ldots, T$

dimana level integrasi $d$ merupakan bilangan real, $\square_{t}$ adalah nilai mean yang berupa konstanta dan $\square_{t} \square \square I I D N \square 0, \square_{\square}^{2} \square$. Filter pembeda $\square^{d}$ disebut Long MemoryFilter (LMF) yang menggambarkanadanya ketergantungan jangka panjang dalam deret. Filter ini diekspansikan sebagai deret Binomial : (Hosking, 1981).
$\nabla^{d}=(1-B)^{d}=\sum_{j=0}^{\infty}\left[\begin{array}{l}d \\ j\end{array}\right](-1)^{j} B^{j}$

$=\left[\begin{array}{l}d \\ 0\end{array}\right\rfloor(-1)^{0} B^{0}+\left[\begin{array}{l}d \\ 1\end{array}\right\rfloor(-1)^{1} B^{1}+\left\lfloor\left[\begin{array}{l}d \\ 2\end{array}\right\rfloor(-1)^{2} B^{2}+\left\lfloor\begin{array}{l}d \\ 3\end{array}\right\rfloor(-1)^{3} B^{3}+\cdots\right.$ $=\frac{d !}{0 !(d-0) !}-\frac{d !}{1 !(d-1) !}+\frac{d !}{2 !(d-2) !}-\frac{d !}{3 !(d-3) !}+\cdots$ $=1-d B+\frac{1}{2}(d-1) d B^{2}-\frac{1}{6}(d-2)(d-1) d B^{3}+$ $=1-d B-\frac{1}{2} d(1-d) B^{2}-\frac{1}{6} d(1-6)(2-d) B^{3}+\cdots$

Asumsi-asumsi pada deret yang fractionally integrated yang harus dipenuhi adalah:

a. $\varnothing(B)$ mempunyai order kurangdari atau sama dengan $p, \varnothing(B)$ mempunyai order kurang dari atau sama dengan $q$, akar-akar $\varnothing(B)$ dan $\varnothing(B)$ diluar unit circle $\varepsilon t \sim I I N D$ (0,)dan $\square_{t} \square I I D N \square 0, \square^{2} \square$

\section{b. Error! Reference source not found.}

c. akar-akar dari $\square \square B \square \square$ sederhana, atau dengan kata lain akar-akar polynomial autoregressive tidak berulang (Sowell, 1992a).

Hosking (1981) menjelaskan bahwa bentuk khusus model ARFIMA adalah proses ARFIMA $(0, d, 0)$ yang mempunyai sifatsifat dasar sebagai berikut :

a. Jika $d<$ Error! Reference source not found., Error! Reference source not found. adalah proses stasioner dan mempunyai orde tak hingga

representasimoving average orde tak hingga.

$$
y_{t}=\Psi(B) \varepsilon_{t}=\sum_{k=0}^{\sim} \Psi_{k} \varepsilon_{t-k}
$$

dimana

$$
\Psi_{k}=\frac{d(1+d)(2+d) \ldots(k-1+d)}{k !}=\frac{(k+d-1) !}{k !(d-1) !}
$$

b. jika $d \square \square$ Error! Reference source not found., Error! Reference source not found. invertibel dan 2 mempunyai representasi autoregressive orde tak hingga

$$
\pi(B) y_{t}-\varepsilon_{t}-\sum_{\substack{k=0 \\ \text { Dimana }}}^{\infty} \pi_{k} y_{t-k}
$$


$\pi_{k}=\frac{-d(1-d)(2-d) \ldots(k-1-d)}{k !}=\frac{(k-d-1) !}{k !(-d-1) !}$

c. Fungsi autokovarian dari $\left\{\mathrm{y}_{\mathrm{t}}\right\}$ adalah

Error! Reference source not found. sehingga fungsi autokorelasi dari $\left\{\mathrm{y}_{\mathrm{t}}\right\}$ adalah:

$\rho_{k}=\frac{\gamma_{k}}{\gamma_{0}}=\frac{(-d) !(k+d-1) !}{(d-1) !(k-d) !}, k=0, \pm 1, \ldots$

Dan Error! Reference source not found. serta Error! Reference source not found.

Pemodelan ARFIMA dapat diperoleh beberapa keuntungan antara lain :

a. Mampu memodelkan perubahan yang tinggi dalam jangka panjang (Long Term Persistence).

b. Mampu menjelaskan struktur korelasi jangka panjang dan jangka pendek sekaligus.

c. Mampu memberikan model dengan parameter yang lebih sedikit (parsimonious) baik untuk data dengan memori jangka panjang maupun jangka pendek. (Hosking, 1981)

\section{Kriteria Seleksi Model}

Untuk memilih model time series yang terbaik maka digunakan beberapa kriteria pemilihan model. Perbandingan ukuran kebaikan model dilakukan berdasarkan kriteria in sample MSE (Mean Square Error) dan AIC (Akaike Information Criterion) serta out of sample MSE, MAD (Mean Absolute Deviation), dan MAPE untuk kesalahan peramalan.

a. Mean Square Error (MSE). MSE untuk model dihitung dari

$$
M S E_{\text {insample }}=\frac{S S E}{n-n_{p}}
$$

Dimana

Error! Reference source not found. Adalah dugaan dari residual Error!

Reference source not found.

$\mathrm{n}$ = banyaknya residual

$\mathrm{n}_{\mathrm{p}}=$ banyaknya parameter yang diduga

Sedangkan MSE untuk ramalan out of sampel dihitung dari

Error! Reference source not found.dimana $\mathrm{M}$ adalah panjang ramalan (Wei, 1990) b. Akaike's Information Criterion

Akaike pada tahun 1973 memperkenalkan suatu pemilihan model terbaik dengan mempertimbangkan banyaknya parameter yang digunakan dalam model. Metode ini muncul karena menganggap bahwa model yang baik tidak cukup hanya dengan menggunakan nilai MSE terkecil, namun juga harus memenuhi prinsip parsimony. Penghitungan nilai AIC adalah sebagai berikut

$$
A I C=n \ln \hat{\sigma}^{2}+2 M
$$

dimana $\mathrm{M}$ adalah banyaknya parameter yang diduga (Wei, 1990)

c. Mean Absolute Deviation (MAD) Salah satu ukuran untuk membandingkan akurasi ramalan adalah MAD yang penghitungannya adalah sebagai berikut :

$M A D=\frac{\sum_{i=1}^{n}\left|e_{i}\right|}{n}$

$\mathrm{n}=$ panjang ramalan (Wei, 1990)

d. MAPE adalah suatu ukuran yang menggambarkan baik tidaknya data hasil forecasting.Hasil forecasting dikatakan baik apabila mempunyai nilai MAPE maksimum $15 \%$, semakin kecil nilai MAPE semakin baik. Berikut rumus perhitungan MAPE :

$$
M A P E=\frac{\sum_{i=1}^{n}\left|\frac{\left(y_{i}-\hat{y}_{i}\right)}{y_{i}}\right|}{n .} .100 \%
$$

\section{METODE PENELITIAN}

Penelitian dilakukan dengan mengambil data sekunder kasus DBD di Rumah Sakit Dr. Hasan Sadikin Bandung untuk periode Januari 2006 sampai dengan Desember 2010 yang diamati secara runtut (berkala) setiap bulan. Variabel dependen dalam penelitian ini adalah kasus DBD (Y), sedangkan variabel independennya adalah waktu (X). Analisis data dilakukan secara statistik dengan bantuan program komputer. 
3. Melakukan analisa statistik dengan menghitung reratanya, standar deviasi, koefisien skewnes.

4. Membuat grafik korelogram autokorelasi dan parsial autokorelasi

\section{Alur Proses Kajian}

Proses peramalan dilakukan secara sistematis, dengan alur proses sebagai berikut, Gambar 3.1.

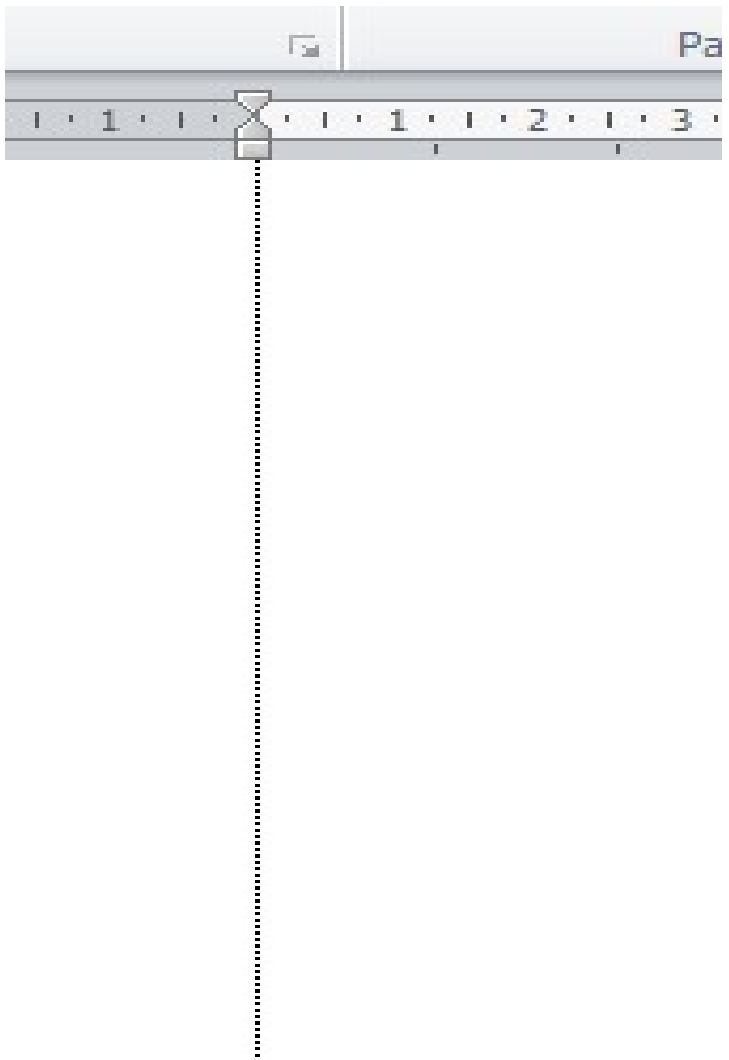

Gambar 3.1. Alur Pikir Forecasting

Analisis data deret waktu untuk forecasting data kasus DBD dilakukan dengan menggunakan metode ARIMA musiman dan ARFIMA. Berikut ini disajikan secara ringkas langkah-langkah praktis dalam proses Forecasting.

\section{Metode ARIMA Musiman}

Langkah-langkah perhitungan untuk pembangkitan data kasus DBD menggunakan metode ARIMA adalah sebagai berikut:

1. Melakukan pengecekan kenormalan data dari data kasus DBD tahunan yang diketahui.

2. Mentransformasi data yang tidak terdistribusi normal dengan menggunakan metode Probability Plot of Correlation Coefficient (PPCC).

5. Menyusun bilangan random dalam distribusi normal menggunakan rumus Box and Muller.

6. Menghitung pemodelan stokastik dengan metode ARIMA dengan rumus sebagai berikut:

$$
\mathrm{Y}_{\mathrm{t}}=\overline{\mathrm{Q}}+\phi_{1} z_{t-1}+\phi_{2} z_{\mathrm{t}-2}+\sigma_{\varepsilon} \cdot \xi_{t}
$$

\section{Metode ARFIMA}

Sesuai dengan tujuan penelitian, maka tahapan penelitian dapat dijelaskan secara garis besar sebagai berikut :

a. Tahap Identifikasi

Cara yang digunakan untuk mengetahui pola dalam data adalah :

- Plot time series.

- Plot ACF dan PACF

- Transformasi Box-Cox untuk data non stasioner varians. (Wei, 1990)

b. Pendugaan Parameter dan Pemeriksaan Diagnostik

Nilai-nilai dari parameter yang ada diperoleh dengan menentukan beberapa model dugaan sementara (dapat lebih dari satu) untuk ARFIMA dengan metode EML, kemudian menduga parameter model dengan dua cara, antara lain :

- Coba-coba, yaitu menguji beberapa nilai yang berbeda kemudian memilih satu nilai tertentu.

- Perbaikan secara iteratif yaitu memilih penduga awal dan membiarkan program komputer

memperhalus dugaan secara iteratif.

Setelah dilakukan pendugaan parameter, kemudian dilakukan pemeriksaan diagnostic yang meliputi uji signifikan parameter, uji white noise residual dan kenormalan residual untuk membuktikan bahwa model tersebut cukup memadai dan apabila tidak maka dicari nilai dugaan yang lain.

c. Penerapan

Model yang memadai digunakan untuk melakukan paramalan out of sample dalam konteks potensi jumlah kasus DBD. 
Ramalan out of sample dilakukan untuk $\mathrm{t}$ tahap waktu ke depan

d. Pemilihan Model terbaik

Untuk memilih model hidrologi time series yang terbaik, digunakan beberapa kriteria pemilihan model seperti in sample MSE dan AIC terkecil serta out of sample MSE dan MAD terkecil untuk kesalahan peramalan, sehingga diperoleh model peramalan jumlah kasus DBD yang cukup handal.

Tahapan proses forecasting dengan metode ARFIMA secara garis besar disajikan dalam alur pikir berikut ini :

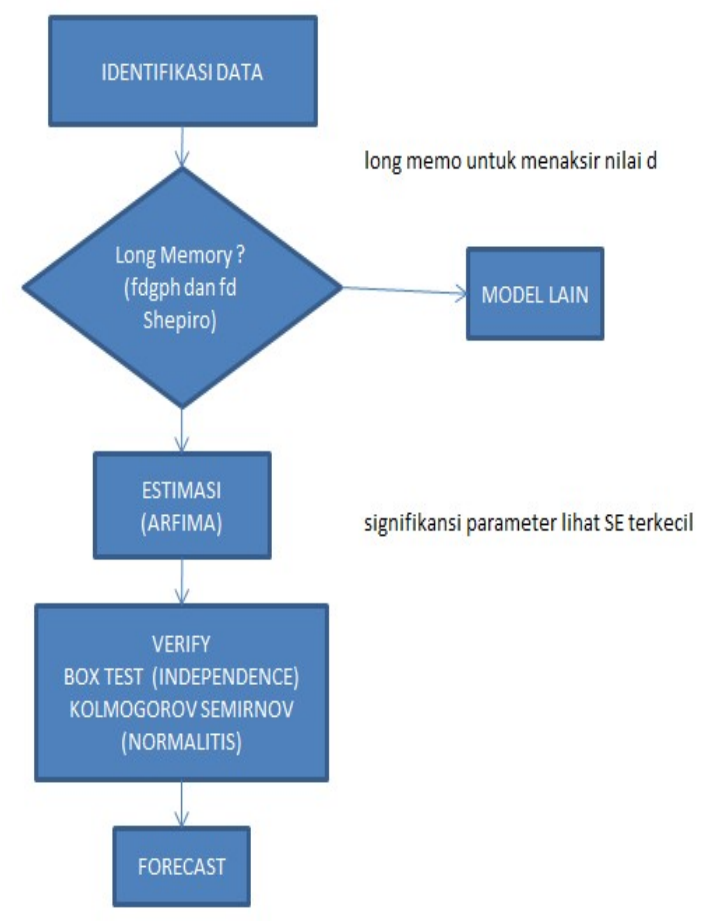

Gambar 3.2. Alur Pikir Forecasting

\section{HASIL PENELITIAN}

Penelitian dilakukan dengan mengambil data sekunder kasus DBD di Rumah Sakit Dr. Hasan Sadikin Bandung untuk periode Januari 2006 sampai dengan Desember 2010 yang diamati secara runtut (berkala) setiap bulan, yang kemudian dilakukan analisis dengan kedua metode peramalan.

\section{Hasil Peramalan dengan Metoda ARIMA} Musiman

Tahap Identifikasi Data Model ARIMA

Sebelum data deret waktu dianalisis dengan menggunakan metode ARIMA, terlebih dahulu diidentifikasi apakah data sudah stasioner di dalam mean dan varians.
Identifikasi data deret waktu merupakan langkah awal yang harus dilakukan dalam proses forecasting, karena dapat memberi informasi mengenai pola dari data diantaranya pola stasioner, trend effect, seasonal effect dan cyclic effect. Identifikasi dapat dilakukan secara visual menggunakan plot data asli, plot ACF dan plot PACF.

Dari hasil analisis langkah dan strategi pembentukan model dengan metode analisis deret berkala ARIMA nampak secara visual berdasarkan hasil pada Gambar 4.1. bahwa plot data asli jumlah kasus demam berdarah di Rumah Sakit Hasan Sadikin mengikuti pola trend musiman dan belum stasioner dalam mean maupun dalam varian. Pada plot ACF berbentuk sinusoidal dan plot PACF terdapat koefisien yang signifikan (memotong garis selang kepercayaan), yaitu 1, 2 dan 5. Secara uji hipotesis dilakukan Augmented DickeyFuller (ADF) Test dan Kwiatkowski-PhillipsSchmidt-Shin (KPSS) test. Dari hasil kedua uji tersebut dengan taraf nyata $5 \%$ diperoleh nilap p 0.405 dan 0.1 lebih besar dari 0.05 , sehingga dapat disimpulkan bahwa data tidak stasioner. Oleh karena itu, harus dilakukan transformasi dan differencing untuk menghilangkan ketidakstasionerannya tersebut.

Identifikasi Plot Time Series dari Jumla|
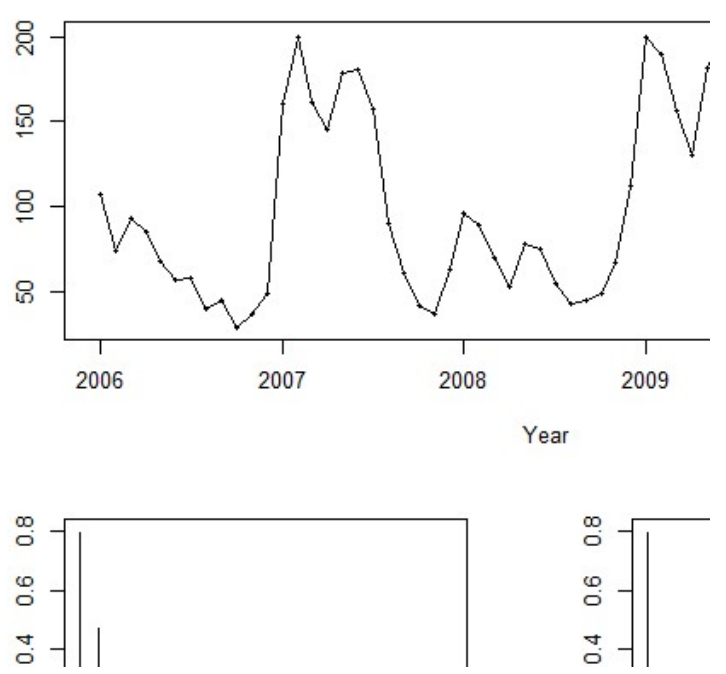

Gambar 4.1 Identifikasi plot data asli sebelum transformasi

Data time series yang belum stasioner dalam varians tersebut selanjutnya ditransformasi menggunakan transformasi transformasi $\log$ dengan bantuan software 
komputer dan kemudian dilakukan proses differencing. Untuk melakukan uji hipotesis pada kasus ini sebelum dan sesudah ditransformasi digunakan Bartlett's test dan Levene's test, kemudian dicari hasil yang terbaik dari kedua uji tersebut. Uji normalitas diperlukan sebelum dilakukan Bartlett's test. Dari Gambaran uji normalitas diperoleh bahwa hasil uji normalitas sebelum transformasi mempunyai nilai $\mathrm{p}<0,001$ yang berarti bahwa data tidak terdistribusi normal. Sedangkan pada uji normalitas setelah transformasi diperoleh nilai $\mathrm{p}>0,150$, Dari hasil Bartlett's test setelah transformasi diperoleh nilai $\mathrm{p}>0.05$, maka berarti menerima hipotesis nol. Jadi disimpulkan bahwa data setelah ditransformasi homogen. Hasil transformasi dan differencing ditunjukkan dalam plot time series (Gambar 4.2).

Seasonally differenced Jumlah Ka
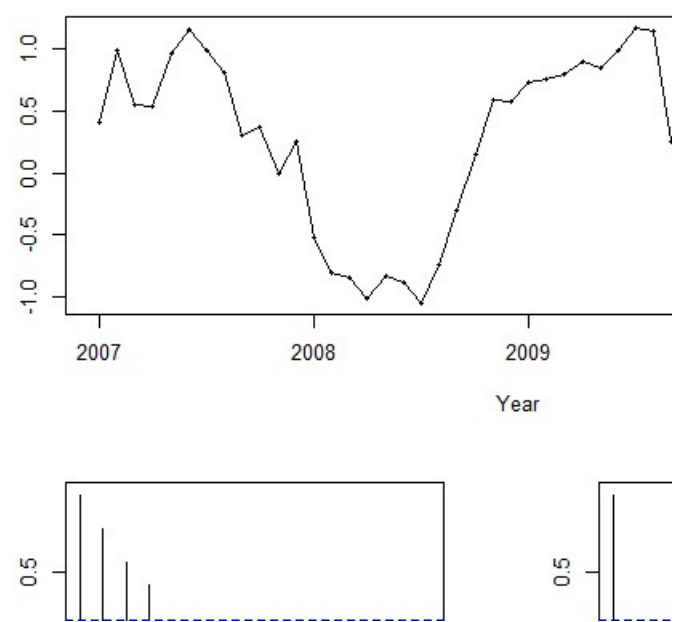

Gambar 4.2 Identifikasi plot data setelah proses transformasi dan differencing

Setelah data dinyatakan telah stasioner maka dilakukan estimasi parameter sementara dengan berdasarkan plot ACF dan PACF. Dari plot ACF berbentuk sinusoidal. Sedangkan pada plot PACF terdapat koefisien yang signifikan (memotong garis selang kepercayaan), yaitu 1, 5 dan 6 , sehingga kemungkinan model yang cocok adalah $\operatorname{ARIMA}(1,0,0)(1,1,0)^{12}$. Untuk lebih meyakinkan maka dari kedua fungsi tersebut dapat diestimasi beberapa model ARIMA yaitu:

$$
\begin{array}{lll}
\text { - } & \text { Model 1 } & \operatorname{ARIMA}(1,0,0)(1,0,0)^{12} \\
\text { - } & \text { Model 2 } & \operatorname{ARIMA}(1,0,0)(1,1,0)^{12}
\end{array}
$$

Jurnal Pendidikan Mandala
- Model 3 ARIMA $(2,0,0)(1,0,0)^{12}$

- Model 4 ARIMA(2,0,0)(1,1,0) ${ }^{12}$

- Model 5 ARIMA $(2,0,0)(2,0,0)^{12}$

- Model 6 ARIMA $(2,0,0)(2,1,0)^{12}$

Tahap Estimasi Parameter Model ARIMA

Langkah selanjutnya adalah melakukan estimasi parameter dari beberapa kemungkinan model ARIMA yang telah diidentifikasi berdasarkan plot ACF dan PACF. Selain itu dengan memanfaatkan fasilitas automatic ARIMA dengan perintah "auto.arima()" pada software R yang dapat memberikan model terbaik. Dalam kasus ini didapat dari hasil auto.arima() adalah sebagai berikut:

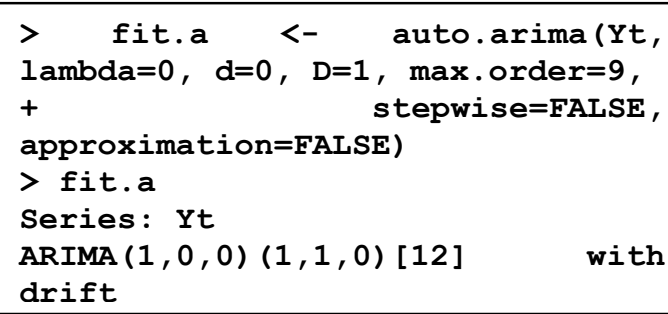

Dari auto.arima() menghasilkan model ARIMA $(1,0,0)(1,1,0)^{12}$ with drift. Selanjutnya masing-masing dilakukan evaluasi terhadap model-model yang telah ada dengan menghitung nilai AIC, BIC dan MSE untuk mendapatkan model yang terbaik.

Tabel.4.1.Perhitungan nilai AIC, BIC dan

\begin{tabular}{|l|l|c|c|c|}
\hline \multicolumn{1}{|c}{ Model } & $\begin{array}{c}\text { AI } \\
\text { C }\end{array}$ & $\begin{array}{c}\text { BI } \\
\text { C }\end{array}$ & $\begin{array}{c}\text { MS } \\
\text { E }\end{array}$ \\
\hline $\begin{array}{l}\text { Mod } \\
\text { el 1 }\end{array}$ & $\begin{array}{l}\text { ARIMA(1,0,0)(1, } \\
0,0)^{12}\end{array}$ & 31.4 & 39.7 & 53.7 \\
8 & 4 \\
\hline $\begin{array}{l}\text { Mod } \\
\text { el 2 }\end{array}$ & ARIMA(1,0,0)(1, & 27.8 & 33.5 & 33.3 \\
1,2 & 9 & & 0 \\
\hline $\begin{array}{l}\text { Mod } \\
\text { el 3 }\end{array}$ & ARIMA(2,0,0)(1, & 26.8 & 37.3 & 56.5 \\
Mod & ARIMA(2,0,0)(1, & 29.2 & 36.7 & 34.3 \\
el 4 & $1,0)^{12}$ & 6 & 5 & 7 \\
\hline $\begin{array}{l}\text { Mod } \\
\text { el 5 }\end{array}$ & ARIMA(2,0,0)(2, & 25.6 & 38.1 & 50.7 \\
\hline Mod & ARIMA(2,0,0)(2, & 31.0 & 40.3 & - \\
el 6 & $1,0)^{12}$ & 2 & 7 & \\
\hline Mod & ARIMA(1,0,0)(1, & 24.3 & 31.8 & 27.3 \\
el 7 & $1,0)^{12}$ with drift & 2 & & 0 \\
\hline
\end{tabular}

Dari hasil perhitungan nilai AIC, BIC dan MSE seperti tercantum pada tabel 4.1, 
didapat bahwa Model 7 yang memakai mode otomatis dari software $\mathrm{R}$ yaitu dengan perintah "auto.arima()"model $\operatorname{ARIMA}(1,0,0)(1,1,0)^{12}$ with drift menghasilkan nilai AIC, BIC, dan MSE terkecil diantara model lainnya.

\section{Tahap Uji Diagnostik Model ARIMA}

Langkah selanjutnya adalah diagnosis model. Diagnosis model dilakukan untuk mendeteksi adanya korelasi dan kenormalan antar residual. Dalam runtun waktu (time series) ada asumsi bahwa residual mengikuti proses white noise yang berarti residual harus independen (tidak berkorelasi) dan berdistribusi normal dengan rata-rata mendekati $0(\mu=0)$ dan standar deviasi $(\sigma)$ tertentu (Iriawan, 2006: 361). Untuk mendeteksi adanya proses white noise, maka perlu dilakukan diagnosis model dengan cara uji independensi residual. Uji dilakukan untuk mendeteksi independensi residual antar lag. Dua lag dikatakan independen (tidak berkorelasi) apabilaantar lag tidak ada korelasi cukup berarti.

Dalam penelitian ini, uji dilakukan dengan membandingkan Ljung-Box $\chi^{2}$ dan nilai Tabel $\chi 2(\alpha, d f)$ pada output proses Ljung-Box-Pierce. Hipotesis: H0: at at $+\mathrm{k} \mathrm{H}$ $\rho=0$ (Ada korelasi antar-lag) dan H1: at at + $\mathrm{k} \rho \neq 0$ (Tidak ada korelasi antar lag atau minimal ada 1 lag yang $\neq$ at at $+\mathrm{k} \rho$ ) Kriteria penolakan $\mathrm{H} 0$ yaitu jika Ljung-Box $\chi^{2}<\chi^{2}$ $(\alpha, d f)$, di mana distribusi $\chi^{2}$ yang digunakan mempunyai df $=k-2$. Maka hasil Ljung-BoxPierce menggunakan software $\mathrm{R}$ adalah sebagai berikut:

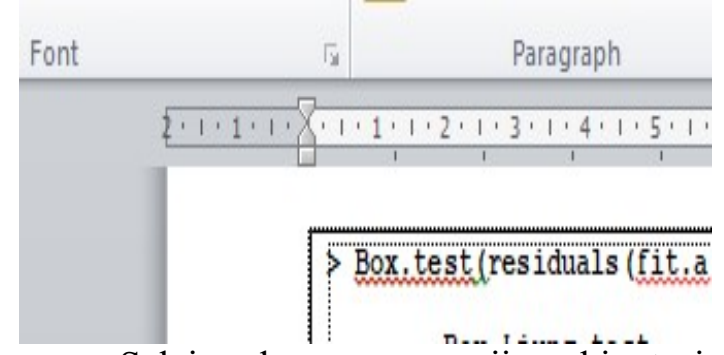

Selain dengan pengujian hipotesis, independensi antar lag akan ditunjukkan pula oleh grafik fungsi autokorelasi (fak) rasidual. Suatu residual model dikatakan telah independen jika tidak ada satu lag pun pada grafik fungsi autokorelasi (fak) residual yang keluar batas garis seperti terlihat pada gambar 4.3.

Jurnal Pendidikan Mandala

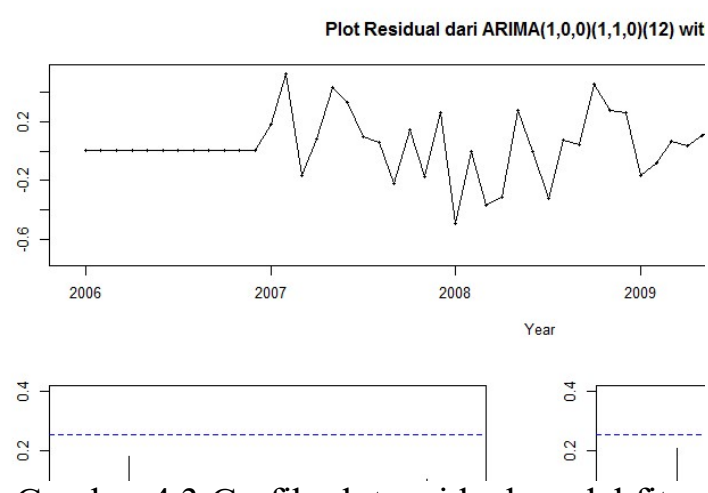

Gambar 4.3 Grafik plot residual model fit ARIMA

Dari hasil uji hipotesis menggunakan Ljung-Box-Pierce, maupun dengan grafik terbukti bahwa proses mengkuti white noise, sehingga tidak ada pelanggaran asumsi dari model terbaik yang dipilih.

\section{Tahap Peramalan Model ARIMA}

Setelah melalui tahap identifikasi, estimasi parameter dan tahap uji diagnostik, maka model terbaik yang didapat adalah model ARIMA $(1,0,0)(1,1,0)^{12}$ with drift. Selanjutnya adalah melakukan peramalan dan hasil yang didapat dengan melakukan peramalan 24 bulan ke depan adalah sebagai berikut:

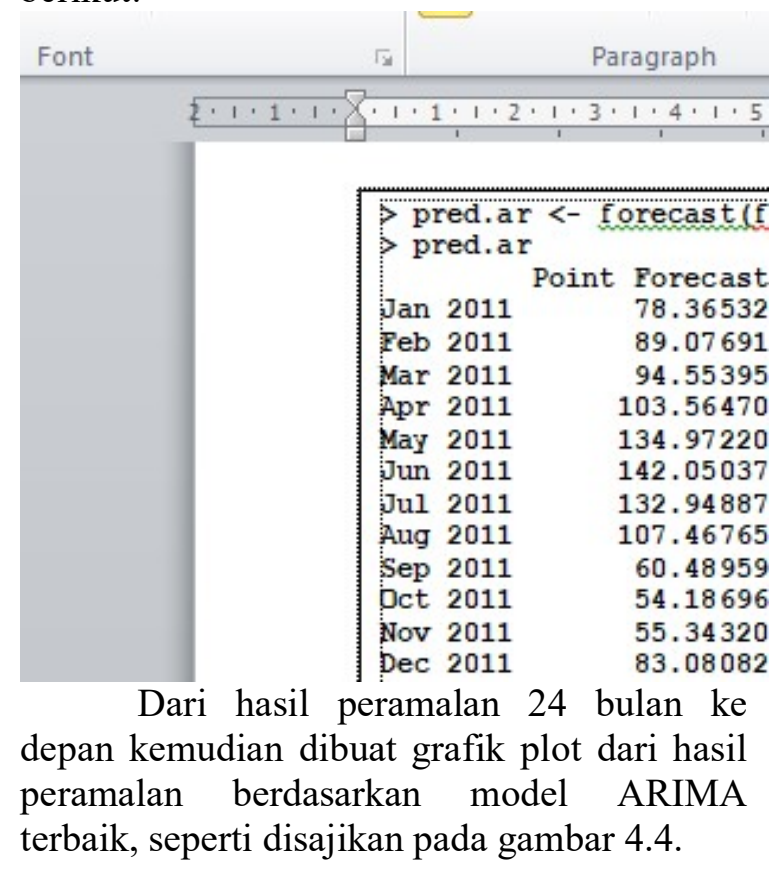


$2 \cdot 1 \cdot 1 \cdot 1 \cdot 8 \cdot 1 \cdot 1 \cdot 1 \cdot 2 \cdot 1 \cdot 3 \cdot 1 \cdot 4 \cdot 1 \cdot 5 \cdot 1$

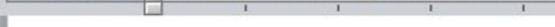

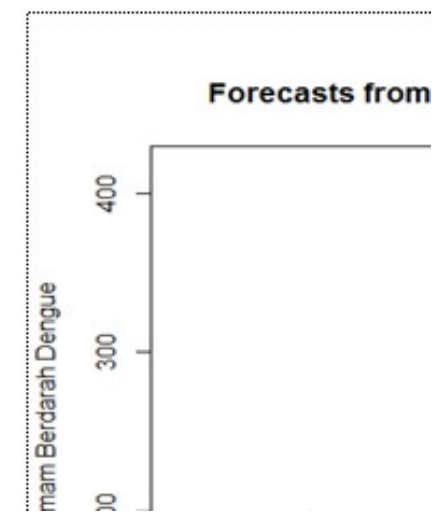

Gambar 4.4 Grafik plot peramalan

Hasil Peramalan dengan Metode ARFIMA

Setelah melakukan forecasting dengan metode ARIMA musiman, adakalanya, plot ACF dan PACF menunjukkan pola long memory, ini terlihat dari nilai-nilai autokorelasi pada plot ACF atau PACF turun secara lambat untuk lag yang semakin meningkat. Identifikasi ini mengindikasikan bahwa nilai dari $d$ (koefisien pembeda, differencing) bernilai pecahan, sehingga model yang paling cocok adalah Model ARFIMA (Autoregressive Fractionally Integrated Moving Average). Proses forecasting menggunakan metode arfima seperti halnya menggunakan metode lainnya diawali dengan identifikasi, kemudian estimasi parameter model, uji diagnostik dan peramalan.

\section{Tahap Identifikasi Data model ARFIMA}

Pada tahap identfikasi data apakah data termasuk long memory atau tidak digunakan software dengan melihat nilai fdGPH dan fdSperio sebagai berikut:

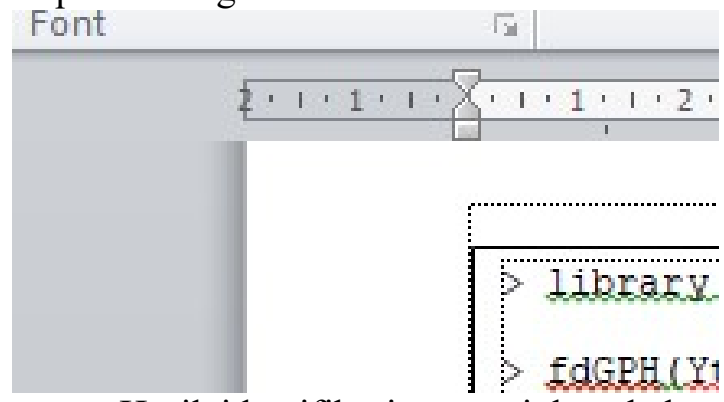

Hasil identifikasi menunjukan bahwa nilai fdGPH dan fdSperio berada sekitar 0,5 dengan demikian bisa dicobakan menggunakan metode ARFIMA dalam proses forecasting.

\section{Tahap Estimasi Parameter Model} ARFIMA

Berikut hasil estimasi parameter model menggunakan metode ARFIMA dengan bantuan Software R.

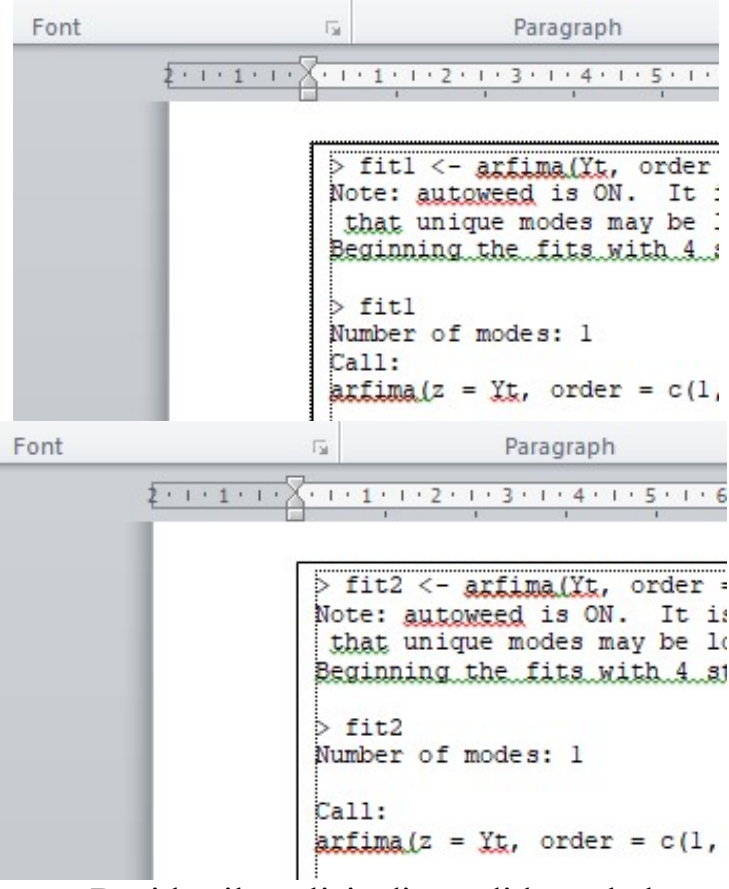

Dari hasil analisis diatas didapat bahwa ARFIMA $(1,1,0)$ memiliki nilai AIC lebih baik dibandingkan ARFIMA $(1,0,0)$.

\section{Tahap Uji Diagnostik Model ARFIMA}

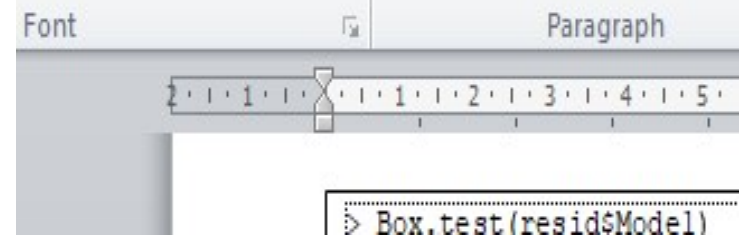

Dari hasil uji hipotesis menggunakan Ljung-Box-Pierce terbukti bahwa proses mengkuti white noise, sehingga tidak ada pelanggaran asumsi dari model terbaik yang dipilih.

\subsubsection{Tahap Peramalan Model ARFIMA}

Berikut hasil forecast jumlah kasus demam berdarah dengue dengan metode ARFIMA dengan bantuan Software " $R$ ". 


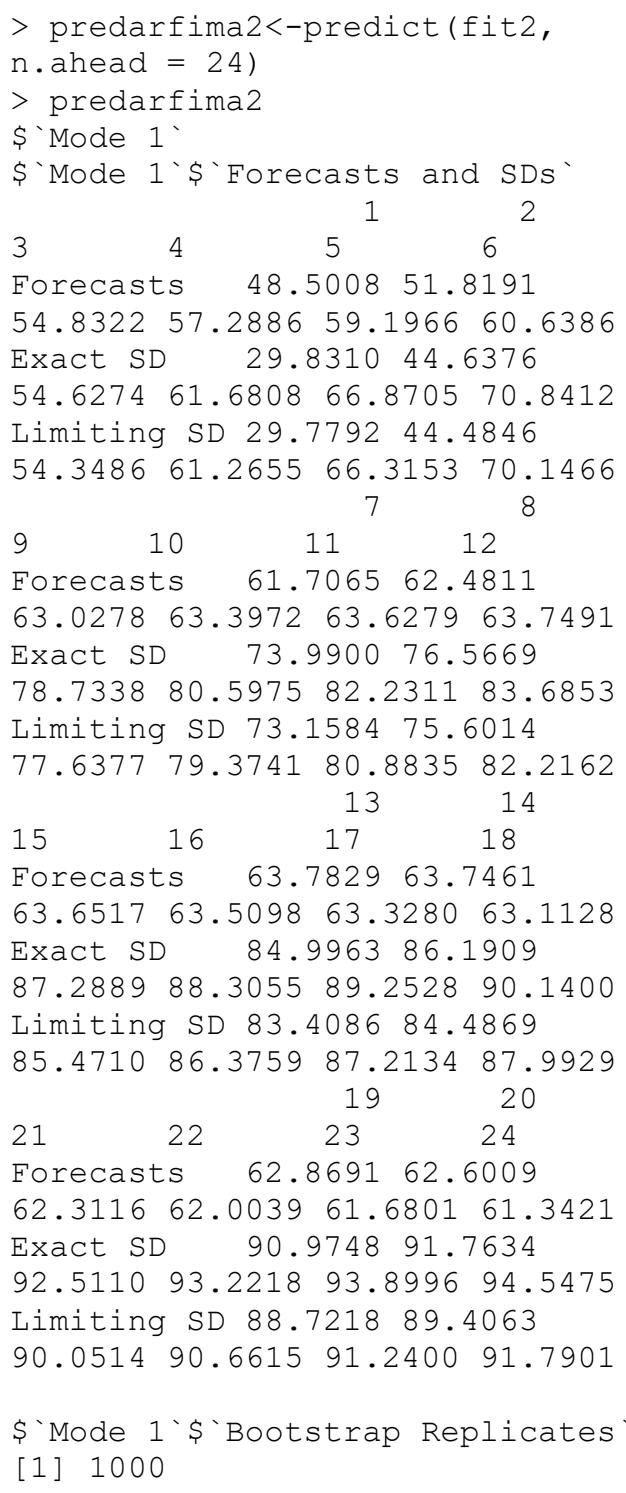

\section{Perbandingan hasil peramalan antara} kedua metode

Untuk mencari model terbaik dalam meramalkan jumlah kasus DBD 24 bulan ke depan, yaitu dengan cara membandingkan nilai MAPE, MAD, MSD. Berikut hasil perbandingan nilai MAPE, MAD, MSD dari kedua model berdasarkan kedua metode analisis peramalan yang telah dilakukan.

Tabel 4.1 Perbandingan Nilai MAPE, MAD dan MSD

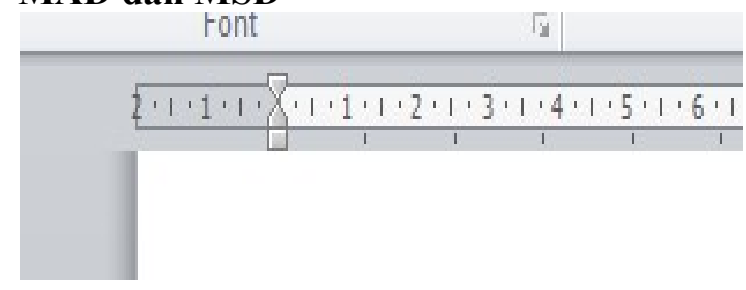

Berdasarkan Tabel. 4.1 menunjukkan bahwa peramalan menggunakan metode SSA menghasilkan nilai MAPE, MAD dan MSD terkecil baik pada insample maupun outsample. Hal membuktikan bahwa metode ARFIMA merupakan metode peramalan yang terbaik dalam membuat peramalan jumlah kasus DBD di Rumah Sakit Hasan Sadikin Bandung.

Tabel 4.2 Perbandingan data insample dan hasil peramalan dari kedua metode
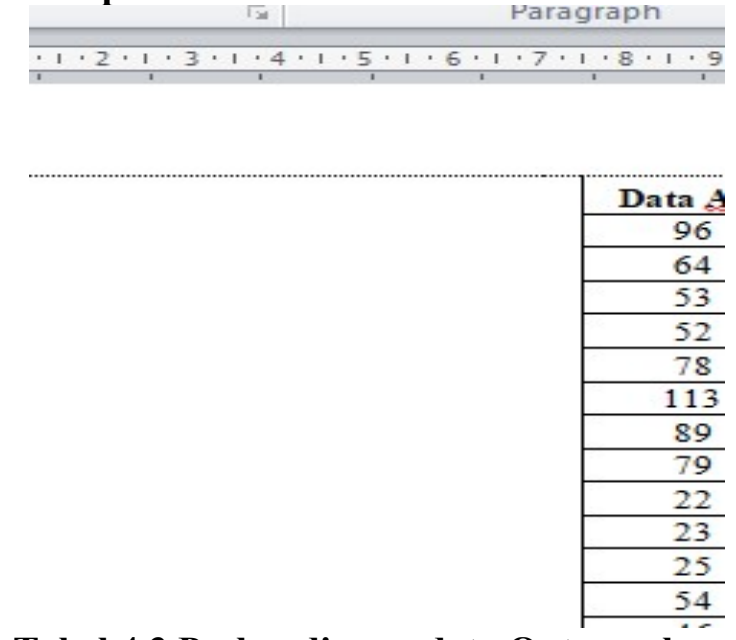

Tabel 4.3 Perbandingan data Outsample dan hasil peramalan dari kedua metode

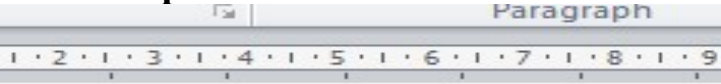




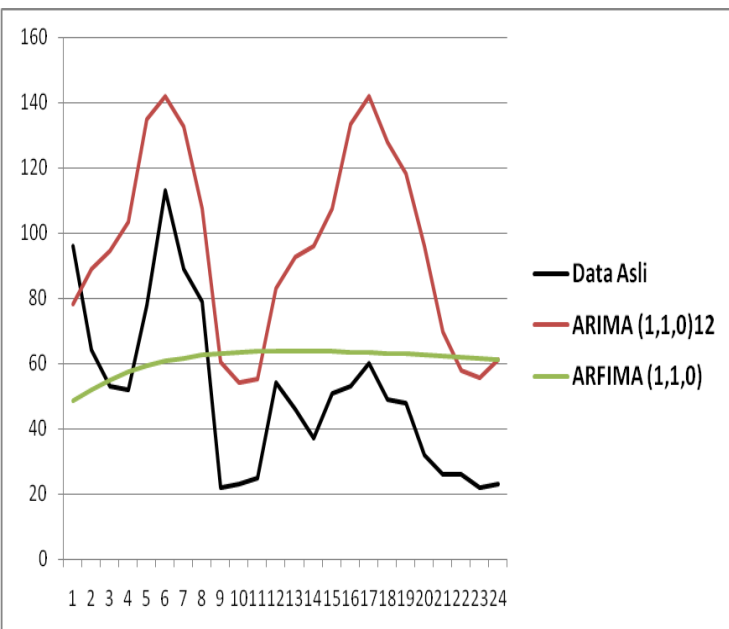

Gambar 4.9. Plot data insample dan hasil peramalan jumlah kasus DBD dari kedua metode peramalan

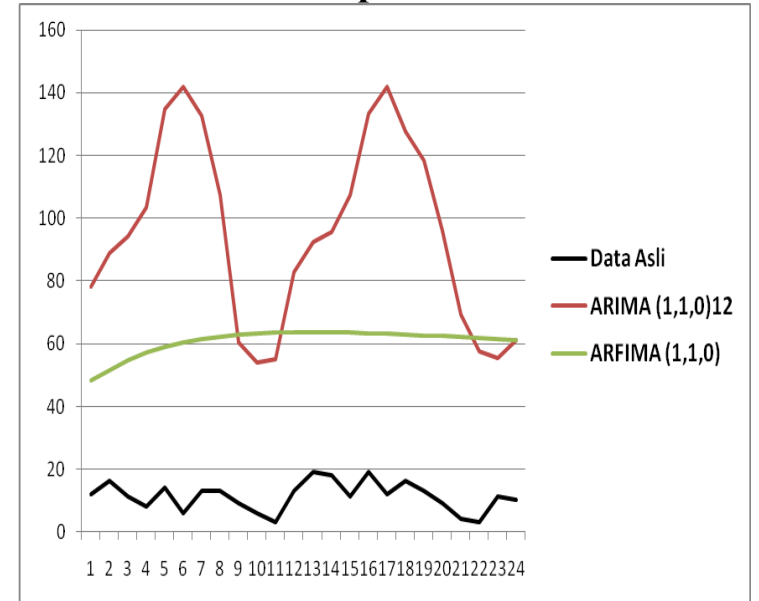

Gambar 4.10. Plot data Outsample dan hasil peramalan jumlah kasus DBD dari kedua metode peramalan

Dari hasil plot data insample maupun outsample dengan hasil peramalan dari kedua metode yang telah dilakukan, menunjukkan bahwa metode peramalan dengan ARFIMA memberikan hasil yang paling mendekati, hal ini terlihat pada Gambar 4.9 dan 4.10.

\section{KESIMPULAN DAN SARAN}

\section{Kesimpulan}

Berdasarkan hasil analisis dan pembahasan yang dilakukan pada bab 4, maka dapat diambil beberapa kesimpulan sebagai berikut:

1. Identifikasi data menunjukan bahwa data jumlah kasus DBD mengikuti pola musiman dengan periode 12 .

2. Hasil peramalan menggunakan ARIMA menghasilkan model ARIMA $(1,0,0)$ $(1,1,0)^{12}$ dengan nilai MAPE sebesar $1.12 \%$, kemudian ARFIMA $(1,1,0)$ dengan nilai MAPE sebesar $0.7 \%$.

Jurnal Pendidikan Mandala
3. Hasil forecasting data jumlah kasus DBD menggunakan kedua metode tersebut memberikan hasil yang cukup baik dengan nilai MAPE lebih kecil dari nilai maksimal MAPE yang masih diperbolehkan yaitu sebesar $15 \%$.

4. Setelah melakukan peramalan dengan metode ARIMA dan ARFIMA maka dapat disimpulkan bahwa Metode ARFIMA adalah metode terbaik untuk menggambarkan dan meramalkan pola atau fluktuasi jumlah kasus DBD dibandingkan dengan metode yang lainnya.

\section{Saran}

Ada beberapa metode peramalan selain dari ARIMA dan ARFIMA yaitu Regresi Spektral. Alangkah baiknya membandingkan metode ARIMA, ARFIMA dan Regresi Spektral untuk menghitung besar nilai MAPE sehingga bisa dibandingkan metode mana yang paling terbaik.

\section{DAFTAR PUSTAKA}

Beran, J. (1994), "Maximum Likelihood Estimation of the Differencing Parameter for Invertible Short and Long Memory Autoregressive Integrated Moving Average Models", Journal of the Royal Statistical Society, Vol. 57, hal. 659672.

Box, G.E.P., \& Jenkins, G.M. 1976. Time Series Analysis, Forecasting and Control. Holden Day: San Francisco.

Cryer,J,D. (1986), "Time Series Analysis", PWS-KENT Publishing Company, Boston,USA.

Darmawan, G. Pengujian Pola Musiman Pada Data Deret Waktu Dengan Menggunakan Regresi Spektral. UNPAD. Bandung 2012.

Depkes RI. 2006. Pemberantasan Sarang Nyamuk Demam Berdarah Dengue (PSN DBD) oleh Juru Pemantau Jentik (Jumantik). Ditjen PP \& PL: Jakarta.

Depkes RI. 2005. Pencegahan dan Pemberantasan Demam Berdarah Dengue di Indonesia. Ditjen PP \& PL: Jakarta.

Depkes RI. 2004. Kajian Masalah Kesehatan Demam Berdarah Dengue, Jakarta. 
www.litbang.depkes.go.id, (sitasi 11 Desember2009).

Granger, C. W. J. dan Joyeux,R. (1980), “An Introduction to Long-Memory Time Series Models and Fractional Differencing", Journal of Time Series Analysis, Vol. 1, hal. 15-29.

Hosking, J.R.M. (1981), "Fractional Differencing”, Biometika, Vol. 68, hal. 165-176.

Ispriyanti, D. 2004. Pemodelan Statistika dengan Transformasi Box Cox, Jurnal Matematika dan Komputer, Vol. 7. No. 3, 8-17.

Makridakis, S., Wheelwright, S. \& Victor, E.M. edition, Erlangga: Jakarta. 1999. Metode dan Aplikasi Peramalan, 2

Makridakis, S., Syeven C.W \& Victor, E.M. 1995. Metode dan Aplikasi Peramalan, Terjemahan Hari Suminto, Binarupa Aksara: Jakarta.

Sowell, F. (1992), "Maximum Lkielihood Estimation of Stationary Univariate Fractionally Integrated Time Series Models", Journal of econometrics, Vol.53, hal. 165 - 188 .

Terasvirta, T., Lin, C.F \& Granger, C.W.J. 1993. Power of The Neural Network Linearity Test, Journal of Time Series Analysis, Vol. 14, p. 159-171.

White, H. 1989. An additional Hidden Unit Test for Neglected Nonlinearity in Multilayer Feed forward Networks. In Proceedings of The International Joint Conference on Neural Networks, pp. 451-455, San Diego, CA: SOS Printing, Washington, DC. 